\title{
Livestock guard dogs reduce predation on domestic sheep in Colorado
}

\author{
WILLIAM F. ANDELT AND STUART N. HOPPER
}

Authors are assistant professor, Department of Fishery and Wildlife Biology, Colorado State University, Fort Collins, Colo. 80523; and former wildlife biol ogy student, 305 Ruth, Fort Collins, Colo. 80525.

Abstract

We surveyed the effectiveness of livestock guard dogs for reducing predation on domestic sheep in Colorado during 1993. The number of producers using dogs increased from about 25 in 1986 to $>159$ in 1993. The proportion of sheep with dogs increased from about $7 \%$ in 1986 to about $68 \%$ in 1993 . Producers with dogs, compared to producers without dogs, lost smaller proportions of their lambs to predators, especially coyotes (Canis latrans Say), and smaller proportions of ewes and lambs to black bears (Ursus americanus Pallas) and mountain lions (Felis concolor L.). Overall, producers who did not have guard dogs lost 5.9 and 2.1 times greater proportions of lambs to predators than producers who had dogs in 1986 and 1993, respectively. Proportions of sheep killed by predators decreased with the number of years that producers used guard dogs. Mortalities of ewes to predators regardless of type of operation and lamb mortality on open range decreased more from 1986 to 1993 for producers who obtained dogs between these years compared to producers who did not have dogs. Of 160 producers using dogs, 84\% rated their dogs overall predator control performance as excellent or good, $13 \%$ as fair, and $3 \%$ as poor. More producers $(n=105)$ indicated effectiveness of their dogs did not change with time, compared to producers $(n=54)$ indicating effectiveness changed. More producers $(n=35)$ also indicated their dogs became more effective over time compared to producers $(n=19)$ indicating their dogs became less effective. Estimates provided by 125 producers indicate that their 392 dogs saved $\$ 891,440$ of sheep from predation during 1993 . A total of 154 of $161(96 \%)$ producers recommend use of guard dogs to other producers.

Key Words: Akbash, black bear, Canis latrans, coyote, dog, Felis concolor, Great Pyrenees, Komondor, mountain lion, sheep, Ursus americanus

Predators kill substantial numbers of domestic sheep in the 17 western states (Pearson 1986, National Agricultural Statistics Service 1995). Several methods have been used to reduce these mortalities (Andelt 1996) including livestock guard dogs (Linhart et al. 1979, McGrew and Blakesley 1982, Coppinger et al. 1983, 1988, Green and Woodruff 1983b 1988 1990, Green et al. 1984, Andelt 1992). Andelt (1992) reported that producers with guard

The authors wish to thank the many sheep producers that responded to this survey. M. G. Fuentes obtained phone numbers of producers and entered the data. K. P. Burnham provided statistical advice. M. K. Johnson provided numerous editorial suggestions which improved the manuscript.

Manuscript accepted 5 Sept. 1999.

\section{Resumen}

Durante 1993 realizamos un reconocimiento para determinar la efectividad de los perros guardianes de ganado bovino para reducir la predación de ovinos domésticos en Colorado. El número de productores que utilizan perros aumentó de aproximadamente 25 en 1986 a mas de 159 en 1993. La proporción de ovinos con perros se incrementó de aproximadamente $7 \%$ en 1896 a aproximadamente $68 \%$ en 1993 . Los productores con perros, comparados con los productores sin perros, perdieron menores proporciones de corderos debido a predadores, especialmente coyotes, (Canis latrans Say) y menores proporciones de borregas debido a osos (Ursus americanus Pallas) y leones de la montaña (Felis concolor $\mathbf{L}$.). En general, las proporciones de perdida de corderos debido a predadores registradas en 1986 y 1993 fueron 5.9 y 2.1 veces mayores que las de los productores que tenían perros. Las proporciones de ovinos asesinados por predadores disminuyo con el numero de años que los productores han utilizado perros guardianes. La mortalidad de borregas por predadores, independientemente del tipo de operación, y la mortalidad de corderos en pastizales abiertos disminuyo mas de 1986 a 1993 para los productores que obtuvieron perros en esos años comparado con los productores que no tenían perros. De 160 productores que utilizan perros, el $84 \%$ califico el control de predadores de sus perros como excelente o bueno, el $13 \%$ como regular y el $3 \%$ como pobre. Mas productores $(n=105)$ indicaron que la efectividad de sus perros no cambio con el tiempo, comparado con $(n=54)$ productores que indicaron que la efectividad si cambio. Mas productores $(n=35)$ también señalaron que con el tiempo sus perros llegan a ser mas efectivos, comparado con los productores $(n=19)$ que indicaron que con el tiempo sus perros fueron menos efectivos. Las estimaciones proporcionadas por 125 productores indican que durante 1993 sus 392 perros evitaron perdidas de ovinos por predadores por un valor de \$ 891,440 dólares. De 161 productores un total de 154 $(96 \%)$ recomendaron a otros productores el uso de perros guardianes.

dogs sustained lower sheep losses to coyotes than producers without dogs. However, no data were available to compare changes in sheep mortalities for producers after they obtained dogs.

Green and Woodruff (1989) and Green et al. (1993) reported that guard dogs repelled black and grizzly bears (Ursus arctos L.) during most encounters. However, no studies have evaluated the effectiveness of dogs against black bear or mountain lion predation, nor have any authors reported on the relative effectiveness of guard dogs for deterring predation by different predators. 
Additional data are also needed to ascertain relationships between herd size, number of dogs/herd, and number of sheep/dog versus predation rates.

In this paper, we compare sheep mortalities to predators for producers in Colorado who had and did not have guard dogs. We present the effects of herd size, sheep/dog, dogs/herd, and number of years dogs were used on predation rates. We report changes in proportions of sheep mortalities from 1986 to 1993 for producers with and without dogs in both years, and producers who obtained dogs between those years.

\section{Materials and Methods}

We determined the effectiveness of guard dogs for protecting domestic sheep from predators by telephone surveys of 182 livestock producers with dogs and 60 producers without dogs during 1993. We believe that our survey included practically all producers who used guard dogs in Colorado. The 60 producers were a random sample of 143 producers who did not have guard dogs and responded to a 1986 survey (Andelt 1992).

We requested information on type of operation, number of ewes and lambs in the operation, ewe and lamb mortalities from all causes (weather, disease, predation, etc.), all predators, and specifically from coyotes, black bears, mountain lions and domestic dogs, ratings of effectiveness, and value of sheep saved based upon mortality rates before and after obtaining dogs, during 1993 or the last year that they used dogs. We compared these data to similar data obtained in 1986 (Andelt 1992).

We classified producer operations with sheep in fenced pastures, open range, fenced pastures plus open range, fenced pastures plus open range and feedlots, and fenced pastures and feedlots as all operations combined. We censored producers with sheep solely in feedlots because these operations usually included large numbers of sheep and low mortalities to predators. We classified operations with sheep in fenced pastures or in a combination of fenced pastures and feedlots as fenced pastures. We conducted separate analyses on fenced pasture versus open range operations because sheep were maintained under different conditions, and we anticipated that sizes of herds and predation rates were different. We defined all predators as the sum of all predators that killed sheep.

We compared the total number of ewes and lambs owned by producers with and without guard dogs. We used total numbers of ewes and lambs owned to calculate mortalities to all causes, but we used the numbers of ewes and lambs that were guarded by dogs, or were not guarded by dogs, when calculating proportions of ewes or lambs killed by predators. For the 1993 survey, we compared mortalities to various predators only among producers who indicated the specific predator was found in their area. Numbers of ewes and lambs killed by predators for producers with guard dogs were reported only for periods when dogs were with sheep. When dogs were not with sheep for the entire year, we extrapolated the mortalities by dividing by the percentage of the annual period that dogs were with sheep to standardize the data for comparisons to producers without dogs.

We compared the numbers of ewes and lambs owned among producers with and without guard dogs using analysis of variance (ANOVA, GLM Procedure, SAS Inst. Inc. 1988) after transforming herd sizes to natural logarithms to equalize variances. We compared the numbers of ewe and lamb mortalities to all causes and to predators among respondents with and without dogs by testing the slopes of regression lines obtained by regressing the number of mortalities against the number of ewes or lambs owned or maintained with dogs. We conducted the analyses with the GLM procedure after weighting the number of mortalities by 1 divided by the number of ewes or lambs owned or by the number of ewes or lambs with dogs. When the overall F-test indicated significant treatment effects, we used 1-sided $\mathrm{z}$ tests with a mean of 0 and a standard deviation of 1 to determine if mortalities for producers with guard dogs were lower than for producers without dogs, whereas 2-sided chi-square tests with 1 degree of freedom were used to determine if mortalities for producers with guard dogs and if mortalities for producers without dogs differed between years. We considered a P < 0.0083 as significant in these 6-treatment comparisons to maintain an experimentwise error rate of 0.05 .

We used linear regression weighted by the number of ewes or lambs with guard dogs (GLM Procedure) to determine the effect of number of ewes or lambs with dogs, number of ewes or lambs/dog, number of dogs/herd, and number of years that dogs were maintained with sheep on the proportion of ewes or lambs killed by predators in individual sheep operations. We determined changes in ewe and lamb mortalities from 1986 to 1993 for produc- ers with and without guard dogs during both years, and for producers who did not have dogs in 1986 but used dogs by 1993 . We assumed that coyotes, black bears, mountain lions, and domestic dogs were found in a producers area during 1986, if they were reported there in 1993, and thus made comparisons between our 1993 and 1986 data for these predators. We determined changes by subtracting proportions of ewe or lamb mortalities in 1986 from those in 1993 for individual producers. We compared these differences among treatments with ANOVA after weighting the differences for each producer by the mean number of ewes or lambs with dogs in 1986 and 1993 in guarded herds.

We assigned rankings to producer ratings $($ excellent $=4$, good $=3$, fair $=2$, poor $=1$, unacceptable $=0$ ) as to effectiveness of dogs for deterring predation by various predators, effectiveness in fenced pastures compared to open range, effectiveness during 1986 compared to 1993 , and compared these rankings with ANOVA using the GLM procedure. We used a binomial probability distribution to determine if the number of producers indicating effectiveness (effectiveness when surveyed compared to effectiveness when the dogs first established normal guarding behaviors) changed, or did not change with time, and if the number of reported positive or negative changes varied from equality. We used Spearman rank correlation to determine if ratings of effectiveness were associated with proportions of ewes or lambs killed by predators. We estimated the value of sheep saved by each guard dog by multiplying the average number of ewes and lambs/producer by differences in predation rates for producers with and without dogs, multiplying by the average value of sheep (\$77; Colorado Agricultural Statistics Service 1994), and dividing by the average number of dogs/producer. We used ANOVA to compare producer estimates of the value of sheep saved/dog between 1986 and 1993, and between fenced pastures versus open range operators after weighting the average saving/dog by number of dogs owned by each producer. We used the "protected" least significant difference test (Milliken and Johnson 1984:31-33) to determine which treatment pairs were different for the average number of ewes and lambs owned, percent changes in ewe and lamb herd sizes, changes in mortalities from 1986 to 1993 and producer ratings of effectiveness of dogs when the overall $\mathrm{F}$ test indicated significant $(\mathrm{P}<0.05)$ treatment effects. 


\section{Results}

\section{Survey response}

We acquired complete or nearly complete surveys from 182 producers who used guard dogs between 1987 and 1993, 54 producers without dogs during 1993, and 6 producers without dogs who last maintained sheep in 1991 and 1992. We discarded 6 surveys for producers who used guard dogs but maintained sheep only in feedlots. Of 161 producers who used dogs for $\geq 1$ year, 144 reported data for 1993 and 17 reported data for the last year that they used dogs (1987 to 1992).

\section{Sheep and dog demographics}

The number of producers using guard dogs who provided complete or nearly complete surveys increased from 25 in 1986 to 159 in 1993 . The number of sheep with dogs in fenced pastures and on open range increased about $900 \%$ from 1986 to 1993 , from $6 \%$ of 340,000 ewes and $8 \%$ of the annual lamb crop of 350,000 in 1986 to $59 \%$ of 325,000 ewes and $76 \%$ of 320,000 lambs in 1993 (Andelt 1992, Colorado Agricultural Statistics Service 1993, 1994, 1995a). An additional 19 producers (17 producers used dogs for $\geq 1$ year and 2 used dogs for $<1$ year) used dogs with 13,650 ewes and 22,500 lambs between 1987 and 1992. Seventeen of 24 producers who used dogs in 1986 (Andelt 1992, and additional data) continued to raise sheep in 1993 and all 17 continued to use dogs. Of the 176 producers with dogs, 83 used Great Pyrenees, 34 used Akbash dogs, 15 used Komondors, 3 used Anatolians, and 41 used combinations of Akbash, Great Pyrenees, Komondors, Maremmas, Shar Planinetz, hybrids, or unknown breeds.

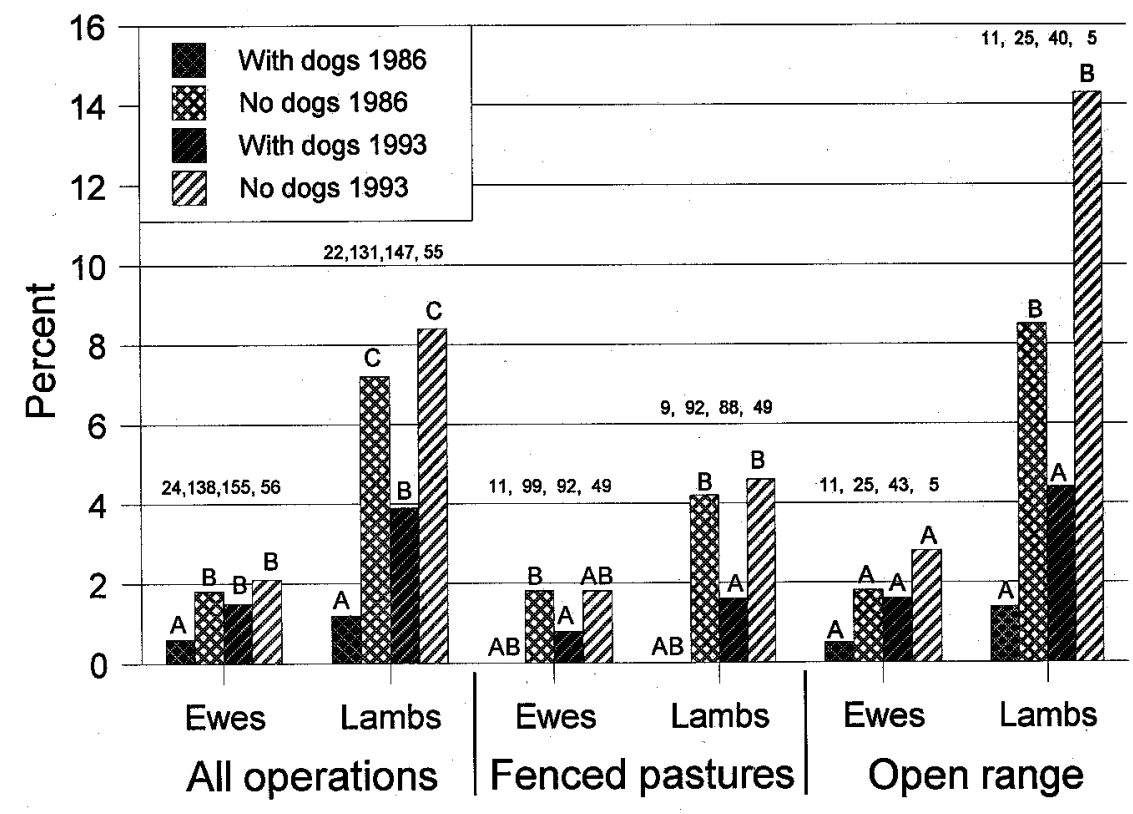

Fig. 1. Percent mortalities of ewes and lambs to predators for producers with animals in fenced pastures (ewes: $P=0.042$; lambs: $P=0.0003$ ), on open range (ewes: $P=0.089$; lambs: $P=<0.0001$ ), and in all operations combined (ewes: $P=0.009$; lambs: $P=$ $<0.0001$ ) in Colorado. Bars, within a group, with the same letters are not significantly different. Sample sizes are above each bar.

\section{Herd sizes}

Regardless of year surveyed, producers who had guard dogs tended to have more sheep than producers without dogs (Tables 1,2). Furthermore, operations with dogs tended to increase in size from 1986 to 1993 whereas operations without dogs tended to decrease in size.

\section{Modalities to all causes}

Producers with guard dogs tended to lose smaller proportions of ewes and particularly lambs than producers without dogs regardless of operation or year of our survey (Tables 1, 2). Overall, mortalities tended to be higher during 1993 compared to 1986 but none of the differences were statistically significant.

\section{Predation}

Producers with guard dogs, compared to producers without dogs, generally lost smaller proportions of ewes and lambs to predators regardless of operation during both survey years (Fig. 1). These comparisons generally were statistically significant for lambs but not as dramatic for ewes. Producers who did not have guard dogs lost 5.9 and 2.1 times greater proportions of lambs to predators than producers who had dogs in 1986 and 1993, respectively. Non-predator mortalities (i.e. mortalities to all causes minus mortalities to all predators; Tables 1, 2; Fig. 1) were similar among producers regardless of whether they owned guard dogs.

Table 1. Mean number ewes/producer and percent mortality from all causes in relation to use of livestock guard dogs reported by sheep producers in Colorado during 1986 and 1993.

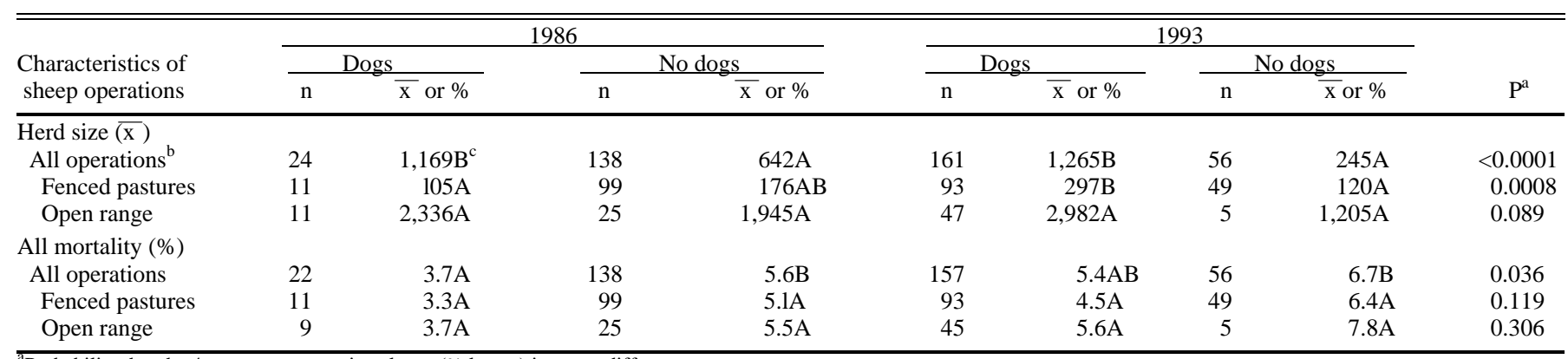

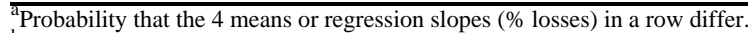

${ }^{b}$ lncludes fenced pasture, open range, fenced pasture — open range, fenced pasture — open range—feedlot, and fenced pasture — feedlot operations.

${ }^{\mathrm{c}}$ Means in a row followed by different letters are different $(\mathrm{P}<0.0083 /$ comparison to obtain an experiment-wise $\mathrm{P} \leq 0.05)$. 
Table 2. Mean number lambs/producer and percent mortality from all causes in relation to use of livestock guard dogs reported by sheep producers in Colorado during 1986 and 1993.

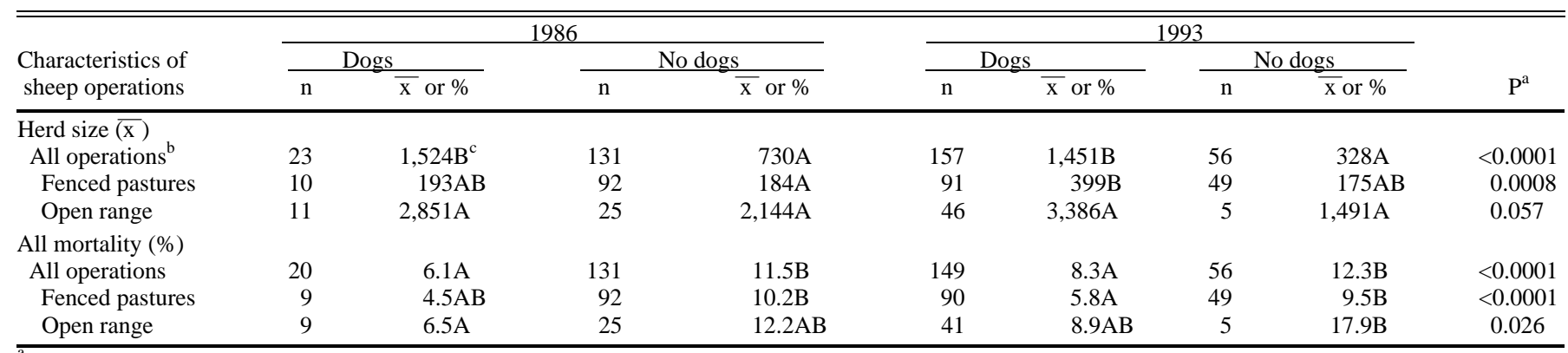

${ }^{\mathrm{a}}$ Probability that the 4 means or regression slopes (\% losses) in a row differ.

${ }^{b}$ Includes fenced pasture, open range, fenced pasture —open range, fenced pasture —open range—feedlot, and fenced pasture - feedlot operations.

${ }^{c}$ Means in a row followed by different letters are different $(\mathrm{P}<0.0083 /$ comparison to obtain an experiment-wise $\mathrm{P} \leq 0.05)$.

Regardless of guard dogs, producers lost similar proportions of ewes to coyotes, but producers with dogs generally lost smaller proportions of lambs (Fig. 2). Producers with guard dogs lost smaller proportions of ewes and lambs to black bears (Fig.3) and mountain lions (Fig. 4) than producers without dogs in all operations combined and on open range. However, guard dogs did not appear to affect predation rates by black bears and mountain lions in fenced pastures where these rates were relatively low. Proportions of ewes and lambs killed by domestic dogs did not vary significantly regardless of the presence of guard dogs for any type of operation (Fig. 5). Coyotes, black bears, and mountain lions

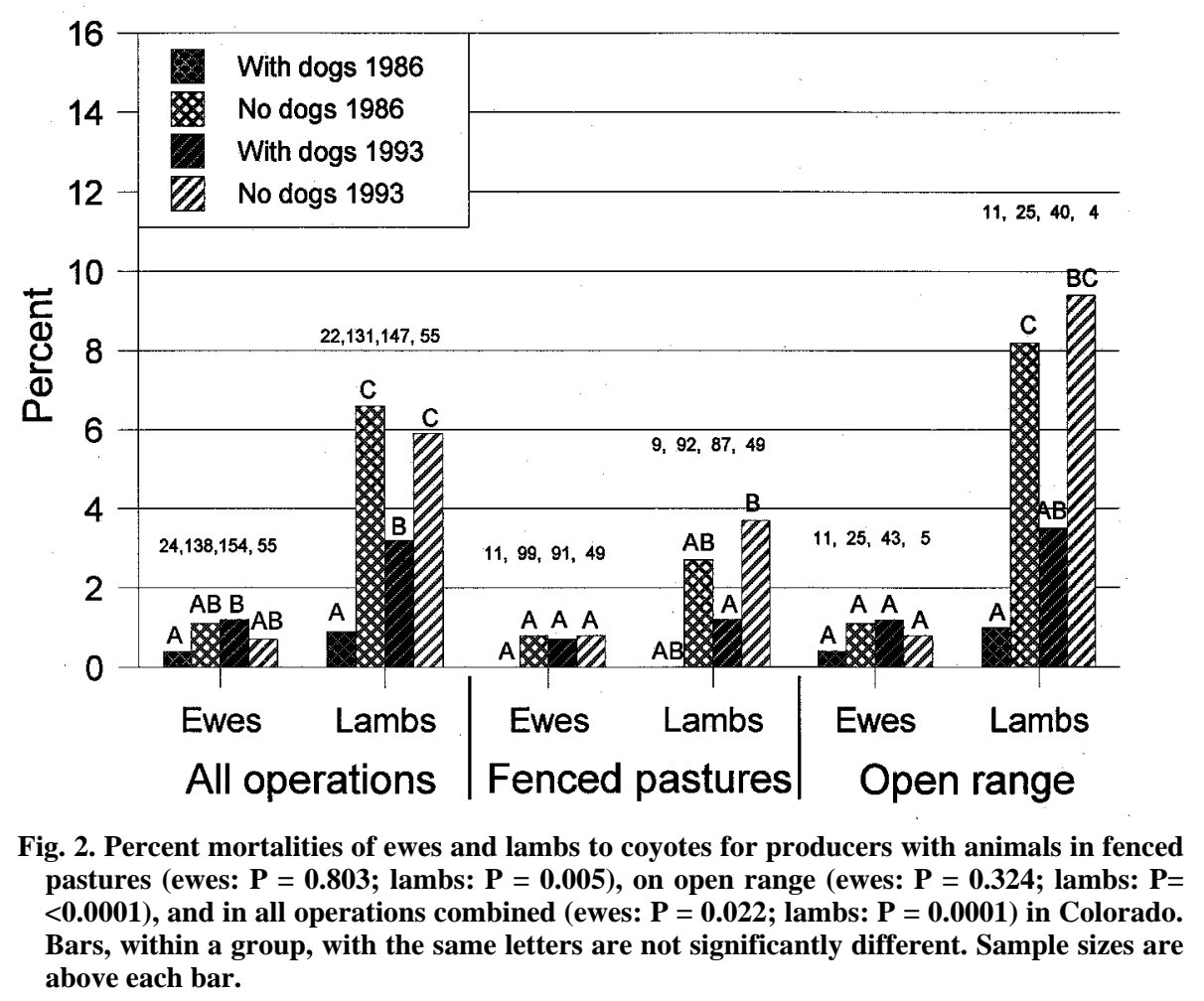

Fig. 2. Percent mortalities of ewes and lambs to coyotes for producers with animals in fenced pastures (ewes: $P=0.803$; lambs: $P=0.005$ ), on open range (ewes: $P=0.324$; lambs: $P=$ $<0.0001$ ), and in all operations combined (ewes: $P=0.022$; lambs: $P=0.0001$ ) in Colorado. Bars, within a group, with the same letters are not significantly different. Sample sizes are above each bar.

generally killed similar proportions of ewes, but coyotes killed 5 to $>10$ times more lambs than either bears or lions.

Five producers with guard dogs and 4 producers without dogs reported that red foxes (Vulpes vulpes L.) killed 262 and 153 lambs, respectively. Four producers with dogs and 1 producer without dogs reported eagles (likely Aquila chrysaetos L.) killed 446 and 40 lambs. In addition, 1 producer with dogs reported American crows (Corvus brachyrhynchos Brehm) killed 2 lambs, and 1 producer indicated that a guard dog killed 2 lambs.

\section{Open range versus fenced pastures}

Mortalities of ewes to predators, and specifically to coyotes, black bears, moun- tain lions, and domestic dogs did not vary significantly $(\mathrm{F}=0.00-2.50 ; 115-132 \mathrm{df}$; $\mathrm{P}=0.117-0.970$, for the various comparisons) between fenced pasture and open range regardless of the presence of guard dogs during either year. However, ewe mortalities to all predators combined were greater $(\mathrm{F}=5.78 ; 1,133 \mathrm{df} ; \mathrm{P}=0.018)$ on open range than in fenced pastures for producers with dogs in 1993. Lamb mortalities were greater $(F=8.35-29.81$; $1,51-126 \mathrm{df} ; \mathrm{P}=<0.0001-0.005$ for the various comparisons) on open range compared to fenced pastures to predators, and specifically to coyotes, for producers without dogs both years and for producers with dogs in 1993. Lamb mortalities to mountain lions also were higher $(\mathrm{F}=8.87 ; 1,22$ df; $\mathrm{P}=0.007$ ) on open range compared to fenced pastures for producers without dogs in 1993. In contrast, lamb mortalities to domestic dogs were higher $(\mathrm{F}=4.29$; $1,100 \mathrm{df} ; \mathrm{P}=0.041$ ) in fenced pastures compared to open range for producers with dogs during 1993.

\section{Relationships: Dog numbers/experience}

Each producer used an average of 3.2 $(\mathrm{SE}=0.3)$ dogs in all operations combined, 1.7 ( $\mathrm{SE}=0.1)$ dogs in fenced pastures, and $5.6(\mathrm{SE}=0.7)$ dogs on open range. Each producer used an average of $1.8(\mathrm{SE}=0.1) \mathrm{dog}$ /herd of sheep in all operations combined, $1.6(\mathrm{SE}=0.1)$ dogs/herd of sheep in fenced pastures, and $2.2(\mathrm{SE}=0.2) \mathrm{dogs} /$ herd of sheep on open range. Each producer had an average of $716(\mathrm{SE}=67)$ ewes and lambs/dog in all operations combined, $414(\mathrm{SE}=77)$ ewes and lambs/dog in fenced pastures, and $1,245(\mathrm{SE}=115)$ ewes and lambs/dog on open range.

Proportions of ewes killed by predators increased as the number of ewes maintained with guard dogs increased in all operations combined (intercept $=0.0057$; 


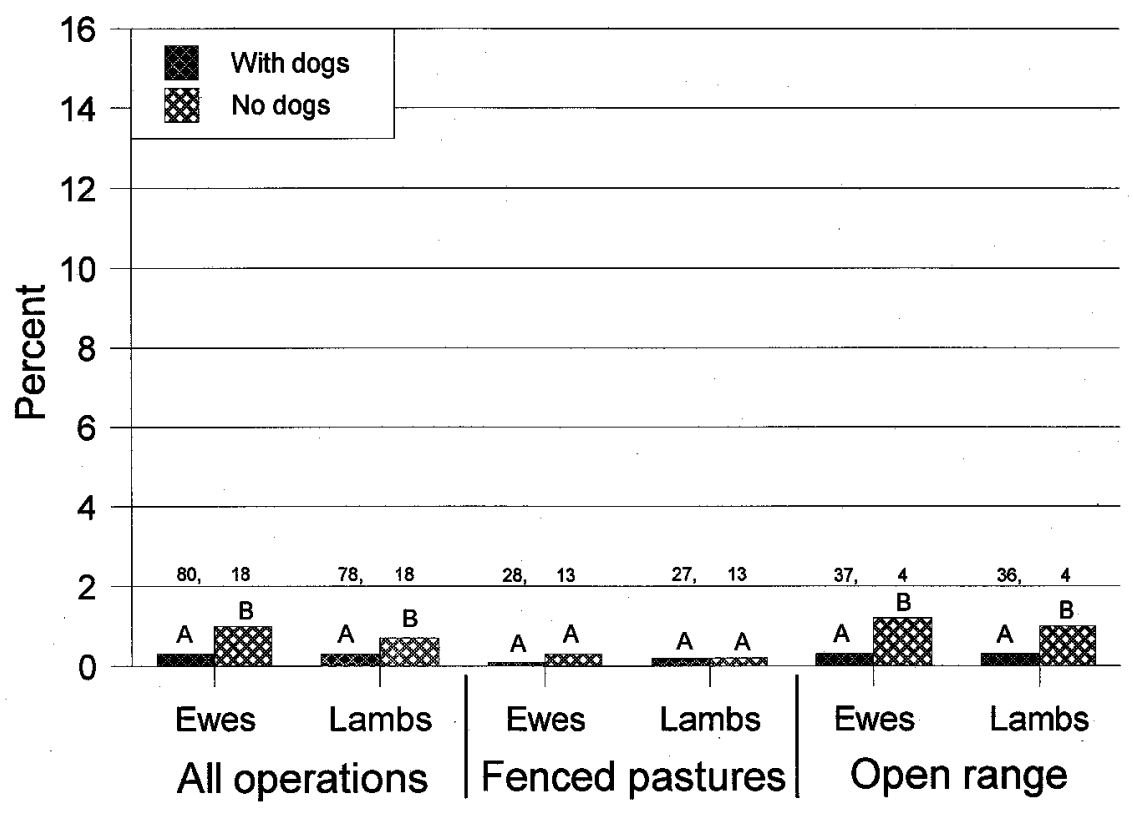

Fig. 3. Percent mortalities of ewes and lambs to black bears for producers with animals in fenced pastures (ewes: $P=0.186$; lambs: $P=0.976$ ), on open range (ewes: $P=0.033$; lambs: $P=0.009$ ), and in all operations combined (ewes: $P=0.002$; lambs: $P=0.005$ ) in Colorado during 1993. Bars, within a group, with the same letters are not significantly different. Sample sizes are above each bar.

slope $=0.0000 ; \mathrm{F}=63.06 ; 1,153 \mathrm{df} ; \mathrm{P}<$ $0.0001)$ and on open range (intercept $=$ $0.0059 ;$ slope $=0.0000 ; \mathrm{F}=28.28 ; 1,41$ df; P $<0.0001$ ), whereas proportions of lambs killed by predators increased as the numbers of lambs with dogs increased only in all operations combined (intercept $=0.0256 ;$ slope $=0.0000 ; \mathrm{F}=17.63$; $1,146 \mathrm{df} ; \mathrm{P}<0.0001)$. Proportions of sheep killed by predators did not vary $(\mathrm{P}=$ $0.168-0.823$ for the various comparisons) by the numbers of ewes or lambs maintained/dog. Also, proportions of sheep killed by predators did not vary $(\mathrm{P}=$ $0.173-0.772$ ) with the number of dogs maintained/herd of sheep regardless of the type of operation. Proportions of ewes and lambs killed by predators decreased with the number of years that individual producers used guard dogs for the analyses of all operations combined (ewes: [intercept $=0.0246 ;$ slope $=-0.0020 ; \mathrm{F}=31.99$; 1,153 df; $\mathrm{P}<0.0001$ ]; lambs: [intercept $=$ $0.0526 ;$ slope $=-0.0029 ; \mathrm{F}=10.44 ; 1,146$ df; $\mathrm{P}=0.002]$ ) and for open range (ewes: [intercept $=0.0264 ;$ slope $=-0.0022 ; \mathrm{F}=$ 20.41; 1,41 df; $\mathrm{P}<0.0001]$; lambs: [intercept $=0.0582 ;$ slope $=-0.0032 ; \mathrm{F}=4.88$; $1,38 \mathrm{df} ; \mathrm{P}=0.033]$ ).

Changes in motality rates from 1986 to 1993

Although generally not statistically significant, predation for our entire sample of producers seemed to increase between
1986 and 1993. However, for the subset of producers who we surveyed during both 1986 and 1993, producers who obtained dogs after 1986 generally had decreases in predation, whereas predation generally increased for producers who did not obtain dogs and predation losses remained about

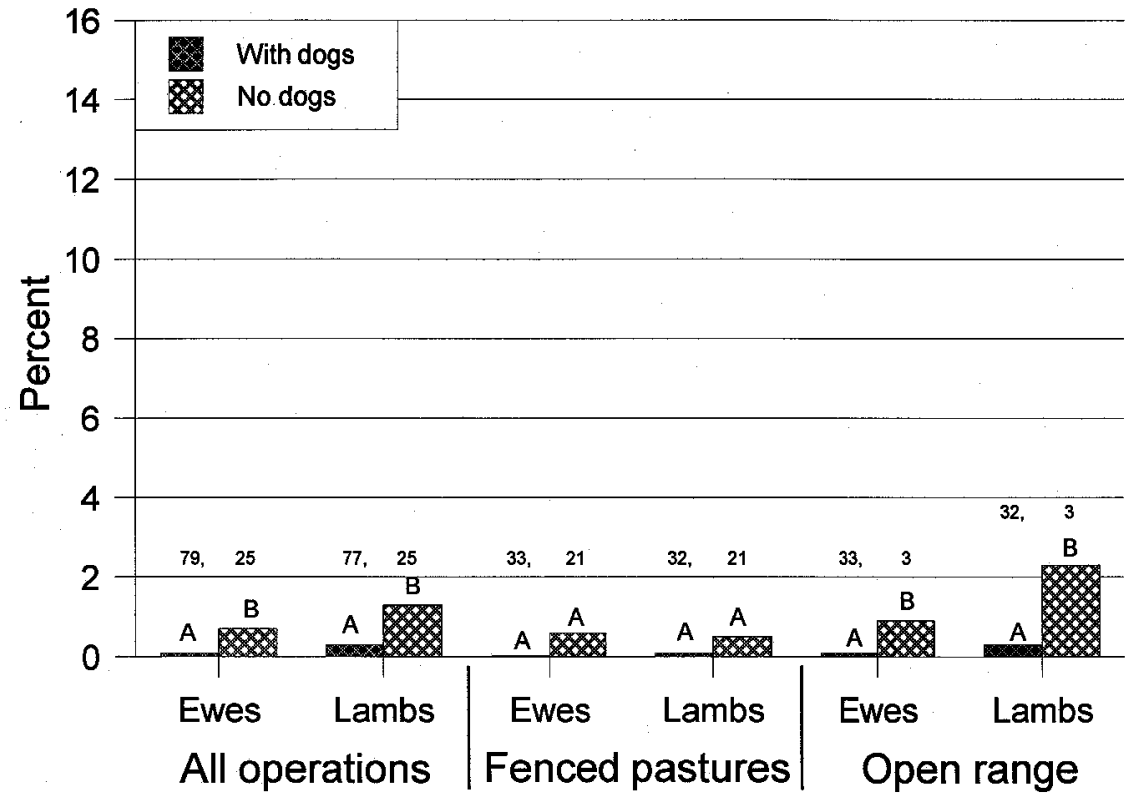

Fig. 4. Percent mortalities of ewes and lambs to mountain lions for producers with animals in fenced pastures (ewes: $P=0.061$; lambs: $P=0.283$ ), on open range (ewes: $P=0.0007$ lambs: $\mathbf{P}=<0.0001$ ), and in all operations combined (ewes: $\mathbf{P}=<0.0001$; lambs: $P=$ $<0.0001$ ) in Colorado during 1993. Bars, within a group, with the same letters are not significantly different. Sample sizes are above each bar. 
Table 3. Mean differences in percent mortalities for ewes from 1986 to 1993 for producers who had guard dogs, did not have guard dogs, and those who obtained guard dogs after 1986 in Colorado. Positive values report increases in predation whereas negative values report decreases.

\begin{tabular}{|c|c|c|c|c|c|c|c|}
\hline \multirow{2}{*}{$\begin{array}{l}\begin{array}{l}\text { Source of } \\
\text { predation loss }\end{array} \\
\end{array}$} & \multicolumn{2}{|r|}{ Dogs } & \multicolumn{2}{|c|}{ No dogs } & \multicolumn{2}{|c|}{ Obtained dogs } & \multirow[b]{2}{*}{$\mathrm{P}^{\mathrm{a}}$} \\
\hline & $\mathrm{n}$ & Difference & $\mathrm{n}$ & Difference & $\mathrm{n}$ & Difference & \\
\hline All predators & & $(\%)$ & & $(\%)$ & & $(\%)$ & \\
\hline All operations & 19 & $-0.1 \mathrm{AB}^{\mathrm{c}}$ & 55 & $0.9 \mathrm{~B}$ & 31 & $-0.9 \mathrm{~A}$ & 0.015 \\
\hline Fenced pastures & 9 & $2.7 \mathrm{~B}$ & 48 & $0.4 \mathrm{AB}$ & 13 & $-3.4 \mathrm{~A}$ & 0.019 \\
\hline Open range & 6 & $-0.2 \mathrm{~A}$ & 3 & $3.3 \mathrm{~B}$ & 6 & $-1.4 \mathrm{~A}$ & 0.023 \\
\hline \multicolumn{8}{|l|}{ Coyotes } \\
\hline All operations & 19 & $-0.1 \mathrm{~A}$ & 54 & $0.1 \mathrm{~A}$ & 31 & $-0.4 \mathrm{~A}$ & 0.381 \\
\hline Fenced pastures & 9 & $2.7 \mathrm{~B}$ & 48 & $0.1 \mathrm{~A}$ & 13 & $-0.3 \mathrm{~A}$ & 0.032 \\
\hline Open range & 6 & $-0.3 \mathrm{~A}$ & 3 & $0.6 \mathrm{~A}$ & 6 & $-1.0 \mathrm{~A}$ & 0.348 \\
\hline \multicolumn{8}{|l|}{ Bears } \\
\hline All operations & 13 & $-0.0 \mathrm{~A}$ & 17 & $0.7 \mathrm{~A}$ & 22 & $0.1 \mathrm{~A}$ & 0.080 \\
\hline Fenced pastures & 4 & $0.0 \mathrm{~A}$ & 12 & $0.2 \mathrm{~A}$ & 7 & $0.2 \mathrm{~A}$ & 0.840 \\
\hline Open range & 6 & $0.1 \mathrm{~A}$ & 3 & $1.6 \mathrm{~A}$ & 6 & $0.2 \mathrm{~A}$ & 0.134 \\
\hline \multicolumn{8}{|l|}{ Lions } \\
\hline All operations & 10 & $0.0 \mathrm{~A}$ & 24 & $0.3 \mathrm{~A}$ & 20 & $-0.4 \mathrm{~A}$ & 0.214 \\
\hline Fenced pastures & 3 & $0.0 \mathrm{~A}$ & 20 & $-0.3 \mathrm{~A}$ & 5 & $0.1 \mathrm{~A}$ & 0.955 \\
\hline Open range & 3 & $0.0 \mathrm{~A}$ & 2 & $1.2 \mathrm{~A}$ & 5 & $-0.8 \mathrm{~A}$ & 0.400 \\
\hline \multicolumn{8}{|l|}{ Dogs } \\
\hline All operations & 18 & $0.0 \mathrm{~A}$ & 45 & $0.2 \mathrm{~A}$ & 21 & $-0.2 \mathrm{~A}$ & 0.739 \\
\hline Fenced pastures & 9 & $0.0 \mathrm{~B}$ & 39 & $0.5 \mathrm{~B}$ & 10 & $-3.7 \mathrm{~A}$ & 0.024 \\
\hline Open range & 5 & $0.0 \mathrm{~A}$ & 3 & $0.0 \mathrm{~A}$ & 4 & $0.2 \mathrm{~A}$ & 0.153 \\
\hline
\end{tabular}

${ }^{\mathrm{a}}$ Probability that the 3 means or regression slopes (\% losses) in a row differ; numerator $\mathrm{df}=2$, denominator $\mathrm{df}=$ sum of ns in a row minus 3 .

$\mathrm{b}$ Includes fenced pasture, open range, fenced pasture — open range, fenced pasture-open range-feedlot, and fenced pasture-feedlot operations.

Means in a row followed by different letters are different.

open range, producers rated guard dogs more effective against coyotes compared to black bears and mountain lions $(\mathrm{F}=$ $3.76,3,118 \mathrm{df} ; \mathrm{P}=0.013)$. Producers rated guard dogs more effective against black bears and mountain lions for sheep in fenced pastures compared to those on open range. Producer ratings of the effectiveness of guard dogs against all predators combined, coyotes, black bears, mountain lions, and domestic dogs were inversely associated $\left(\mathrm{n}=39-154 ; \mathrm{r}_{\mathrm{s}}=\right.$ $-0.262--0.557 ; \mathrm{P}=0.043-<0.0001)$ with proportions of sheep killed by these predators. A total of 154 of 161 (96\%) guard dog owners indicated they would recommend dogs to other livestock producers, whereas 3 owners indicated they would recommend dogs only under certain conditions, and 4 owners would not recommend dogs.

\section{Changes in effectiveness}

Producer ratings of the effectiveness of guard dogs for deterring predation by all predators combined were similar $(\mathrm{F}=$ $0.06 ; 1,180 \mathrm{df} ; \mathrm{P}=0.807$ ) during 1986 (n $=22, \overline{\mathrm{x}}=3.5)$ and $1993(\mathrm{n}=160, \overline{\mathrm{x}}=3.5)$. During 1993, more $(\mathrm{P}<0.0001)$ producers $(\mathrm{n}=105$, including 64 producers in fenced pastures and 24 producers on open range) indicated effectiveness of their dogs did not change with time compared to those (n producers $(\mathrm{n}=35$, including 19 producers who used fenced pastures and 14 producers who used open range) indicated their dogs were more effective compared to those $(\mathrm{n}=19$, including 10 producers who used fenced pastures and 8 producers who used open range) who indicated their dogs were less effective. Of the producers indicating their dogs were more effective, 29 attributed the better performance to maturity of the dogs, 3 indicated more effective dogs were used, and 2 indicated that their dogs learned to outsmart predators. Three producers indicated the federal animal damage control program was more effective than before, and 3 others indicated their own predator control efforts increased.

Of the producers indicating their dogs were less effective, 11 felt predators learned to outsmart the dogs, 4 indicated the dogs changed their behaviors, 3 indicated there were more predators, 3 indicated the dogs became too old, 2 indicated that predator control efforts decreased and 3 producers gave other reasons. Producer ratings of the effectiveness of guard dogs for deterring predation on sheep were not related $($ rating $=3.29+0.03$ years; $F=$ $3.39 ; 1,158 \mathrm{df} ; \mathrm{P}=0.068$ ) to the number of years that producers used dogs.

$=54$, including including 29 producers who used fenced pastures and 22 producers who used open range) who indicated effectiveness changed. More $(\mathrm{P}=0.010)$

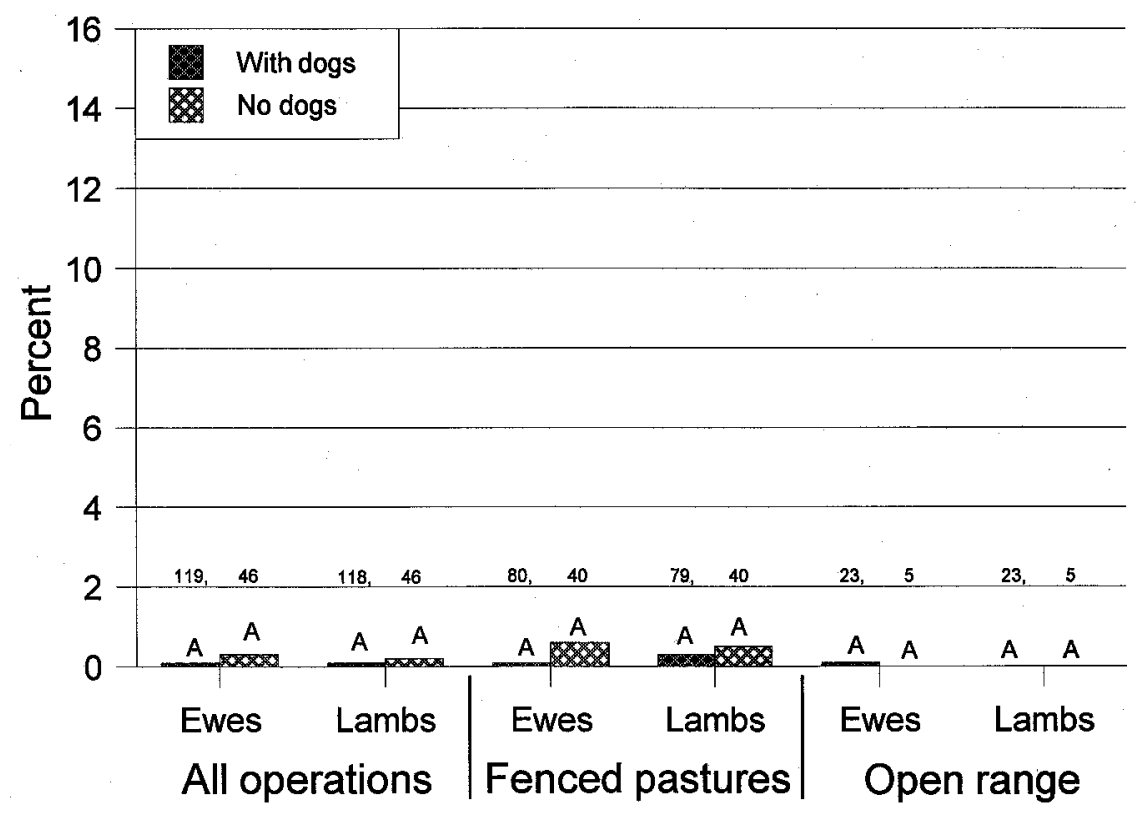

Fig. 5. Percent mortalities of ewes and lambs to domestic dogs for producers with animals in fenced pastures (ewes: $P=0.201$; lambs: $P=0.532$ ), on open range (ewes: $P=0.443$; lambs: $P=1.000$ ), and in all operations combined (ewes: $P=0.442$; lambs: $P=0.482$ ) in Colorado during 1993. Bars, within a group, with the same letters are not significantly different. Sample sizes are above each bar. 
Table 4. Mean differences in percent mortalities for lambs from 1986 to 1993 for producers who had guard dogs, did not have guard dogs, and those who obtained guard dogs after 1986 in Colorado. Positive values report increases in predation whereas negative values report decreases.

\begin{tabular}{|c|c|c|c|c|c|c|c|}
\hline \multirow{2}{*}{$\begin{array}{l}\begin{array}{l}\text { Source of } \\
\text { predation loss }\end{array} \\
\end{array}$} & \multicolumn{2}{|c|}{ Dog } & \multicolumn{2}{|c|}{ No dogs } & \multicolumn{2}{|c|}{ Obtained dogs } & \multirow[b]{2}{*}{$\mathrm{P}^{\mathrm{a}}$} \\
\hline & $\mathrm{n}$ & Difference & $\mathrm{n}$ & Difference & $\mathrm{n}$ & Difference & \\
\hline All predators & & $(\%)$ & & $(\%)$ & & $(\%)$ & \\
\hline All operations ${ }^{b}$ & 17 & $0.7 \mathrm{~A}^{\mathrm{c}}$ & 55 & $3.0 \mathrm{~A}$ & 27 & $0.7 \mathrm{~A}$ & 0.162 \\
\hline Fenced pastures & 7 & $5.3 \mathrm{~A}$ & 48 & $-0.7 \mathrm{~A}$ & 11 & $-1.8 \mathrm{~A}$ & 0.183 \\
\hline Open range & 6 & $0.2 \mathrm{~A}$ & 3 & $9.2 \mathrm{~B}$ & 6 & $-0.3 \mathrm{~A}$ & 0.006 \\
\hline \multicolumn{8}{|l|}{ Coyotes } \\
\hline All operations & 17 & $0.8 \mathrm{~A}$ & 54 & $1.5 \mathrm{~A}$ & 27 & $0.5 \mathrm{~A}$ & 0.637 \\
\hline Fenced pastures & 7 & $5.3 \mathrm{~A}$ & 48 & $0.0 \mathrm{~A}$ & 11 & $-1.0 \mathrm{~A}$ & 0.156 \\
\hline Open range & 6 & $0.2 \mathrm{~A}$ & 3 & $6.2 \mathrm{~B}$ & 6 & $-0.5 \mathrm{~A}$ & 0.009 \\
\hline \multicolumn{8}{|l|}{ Bears } \\
\hline All operations & 12 & $-0.1 \mathrm{~A}$ & 18 & $0.1 \mathrm{~A}$ & 18 & $0.4 \mathrm{~A}$ & 0.054 \\
\hline Fenced pastures & 3 & $0.0 \mathrm{~A}$ & 13 & $0.2 \mathrm{~A}$ & 5 & $0.7 \mathrm{~A}$ & 0.468 \\
\hline Open range & 6 & $0.0 \mathrm{~A}$ & 3 & $0.3 \mathrm{~A}$ & 6 & $0.5 \mathrm{~A}$ & 0.353 \\
\hline \multicolumn{8}{|l|}{ Lions } \\
\hline All operations & 9 & $0.0 \mathrm{~A}$ & 25 & $0.3 \mathrm{~A}$ & 16 & $0.6 \mathrm{~A}$ & 0.467 \\
\hline Fenced pastures & 2 & $0.0 \mathrm{~A}$ & 21 & $-1.4 \mathrm{~A}$ & 3 & $0.0 \mathrm{~A}$ & 0.690 \\
\hline Open range & 3 & $0.0 \mathrm{~A}$ & 2 & $2.4 \mathrm{~B}$ & 5 & $1.0 \mathrm{~A}$ & 0.015 \\
\hline \multicolumn{8}{|l|}{ Dogs } \\
\hline All operations & 16 & $0.0 \mathrm{~A}$ & 45 & $0.1 \mathrm{~A}$ & 20 & $-0.1 \mathrm{~A}$ & 0.934 \\
\hline Fenced pastures & 7 & $0.0 \mathrm{~A}$ & 39 & $0.2 \mathrm{~A}$ & 9 & $-0.9 \mathrm{~A}$ & 0.664 \\
\hline Open range & 5 & $0.0 \mathrm{~A}$ & 3 & $0.0 \mathrm{~A}$ & 4 & $0.0 \mathrm{~A}$ & 1.000 \\
\hline
\end{tabular}

${ }^{\mathrm{a}}$ Probability that the 3 means or regression slopes (\% losses) in a row differ; numerator $\mathrm{df}=2$, denominator $\mathrm{df}=$ sum of ns in a row minus 3 .

${ }^{\mathrm{b}}$ Includes fenced pasture, open range, fenced pasture —open range, fenced pasture —open range—feedlot, and fenced pasture-feedlot operations.

${ }^{c}$ Means in a row followed by different letters are different.

Table 5. Producer ratings of the effectiveness of livestock guard dogs for deterring predators from preying on domestic sheep in Colorado during 1993.

\begin{tabular}{|c|c|c|c|c|c|c|c|}
\hline \multirow[b]{2}{*}{ Predator } & \multicolumn{2}{|c|}{ All operations } & \multicolumn{2}{|c|}{ Fenced pastures } & \multicolumn{2}{|c|}{ Open range } & \multirow[b]{2}{*}{$\mathrm{P}^{\mathrm{b}}$} \\
\hline & $\mathrm{n}$ & $\bar{x}$ & $\mathrm{n}$ & $\overline{\mathrm{x}}^{\mathrm{a}}$ & $\mathrm{n}$ & $\overline{\mathrm{x}}$ & \\
\hline All predators & 160 & 3.46 & 92 & 3.57 & 47 & 3.33 & 0.088 \\
\hline Coyotes & 160 & $3.49 \mathrm{C}^{\mathrm{c}}$ & 92 & $3.58 \mathrm{~A}$ & 47 & $3.38 \mathrm{~B}$ & 0.160 \\
\hline Black bears & 64 & $2.93 \mathrm{~A}$ & 16 & $3.38 \mathrm{~A}$ & 35 & $2.76 \mathrm{~A}$ & 0.038 \\
\hline Mountain lions & 43 & $3.02 \mathrm{AB}$ & 17 & $3.47 \mathrm{~A}$ & 19 & $2.61 \mathrm{~A}$ & 0.022 \\
\hline Domestic dogs & 109 & $3.30 \mathrm{BC}$ & 73 & $3.36 \mathrm{~A}$ & 21 & $3.05 \mathrm{AB}$ & 0.193 \\
\hline
\end{tabular}

a $4=$ excellent, 3 = good, 2 = fair, $1=$ poor, $0=$ unacceptable.

${ }^{\mathrm{b}}$ Probability that the means for fenced pastures and open range do not differ.

${ }^{c}$ Means in a column followed by the same letter do not differ $(\mathrm{P}<0.05)$.

\section{Estimated savings/dog}

Estimates, by producers who used guard dogs for $\geq 1$ year, of the average value of sheep saved/dog from predators within all operations combined were similar $(\mathrm{F}=$ $0.97 ; 1,134 \mathrm{df} ; \mathrm{P}=0.327)$ during $1986(\mathrm{n}$ $=12$ producers $)$ and $1987-1993(\mathrm{n}=124$ producers; Table 6). Estimates of the average value of sheep saved/dog from predators within fenced pastures also were simi$\operatorname{lar}(\mathrm{F}=0.27 ; 1,72 \mathrm{df} ; \mathrm{P}=0.604)$ during $1986(\mathrm{n}=5$ producers $)$ and $1987-1993(\mathrm{n}$ $=69$ producers), and savings on open range were similar $(\mathrm{F}=0.04 ; 1,41 \mathrm{df} ; \mathrm{P}=$ 0.840 ) during 1986 ( $\mathrm{n}=6$ producers) and $1987-1993$ ( $\mathrm{n}=37$ producers). Producers estimated that each dog saved a greater value of sheep on open range than within fenced pastures during both $1986(\mathrm{~F}=$ we estimated that the average value of sheep saved/dog was somewhat lower than producer estimates in all operations combined and fenced pastures, but higher on open range (Table 6).

Estimated savings during 1993 by 114 producers $(\overline{\mathrm{x}}=\$ 2,276)$ who used 374 dogs for $\geq 1$ year and 11 producers $(\bar{x}=\$ 2,242)$ who used $18 \mathrm{dogs}$ for $<1$ year totaled $\$ 891,440$. Estimates provided by 12 of 19 producers who used dogs between 1987 and 1992 but not during 1993 indicated that each of their 24 dogs saved an average of $\$ 5,986$ of sheep annually from predation.

The number of guard dogs used by individual producers increased with the number of sheep maintained with dogs in all operations combined (number dogs $=1.90$ +0.00050 x number sheep; $F=73.76$; $1,122 \mathrm{df} ; \mathrm{P}=<0.0001)$ and on open range (number dogs $=3.36+0.00038 \mathrm{x}$ number sheep; $\mathrm{F}=8.00 ; 1,35 \mathrm{df} ; \mathrm{P}=0.008)$, but not in fenced pastures (number dogs $=$ $1.62+0.00009 \times$ number sheep; $F=1.30$; $1,67 \mathrm{df} ; \mathrm{P}=0.259)$. Producer estimates of the value of sheep saved from predators by each dog during 1987-1993 were directly related to the number of ewes and lambs that producers maintained with dogs in all operations combined ( saved $=1,424+$ $0.33 \times$ number ewes and lambs; $\mathrm{F}=17.38$; $1,122 \mathrm{df} ; \mathrm{P}<0.0001)$ and in fenced pastures (saved $=558+0.85 \mathrm{x}$ number ewes and lambs; $\mathrm{F}=57.00 ; 1,67 \mathrm{df} ; \mathrm{P}<$ 0.0001 ), but not on open range (saved $=$ $3,212+0.22 \times$ number ewes and lambs; $F$ $=1.39 ; 1,35 \mathrm{df} ; \mathrm{P}=0.247$ ).

\section{Discussion}

We found that 7 of 24 producers using guard dogs in 1986 stopped raising sheep by 1993 . This rate of going out of business is similar to an overall rate of decline in the number of sheep producers from $2,200-2,600$ in the 1980 's to 1,800 in $(\mathrm{F}=8.55 ; 1,104 \mathrm{df} ; \mathrm{P}=0.004)$. From our data on herd sizes, predation rates, value of sheep, and number of dogs/producer,

Table 6. Producer estimates and our estimate of the average value (dollars) of domestic sheep saved from predators by each guard dog in Colorado during 1986 and 1993.

\begin{tabular}{|c|c|c|c|c|c|c|}
\hline \multirow[b]{2}{*}{ Year } & \multicolumn{2}{|c|}{ All operations } & \multicolumn{2}{|c|}{ Fenced pastures } & \multicolumn{2}{|c|}{ Open range } \\
\hline & $\mathrm{n}^{\mathrm{a}}$ & $\overline{\mathrm{X}}$ & $\mathrm{n}$ & $\overline{\mathrm{X}}$ & $\mathrm{n}$ & $\bar{x}$ \\
\hline \multicolumn{7}{|c|}{ Producer } \\
\hline 1986 & 33 & 3,733 & 7 & 686 & 24 & 4,100 \\
\hline 1993 & 396 & 2,506 & $116.5^{\mathrm{c}}$ & 1,149 & 202.5 & 3,610 \\
\hline \multicolumn{7}{|c|}{ Authors } \\
\hline 1993 & & $1,685^{\mathrm{d}}$ & & 683 & & 4,832 \\
\hline
\end{tabular}

${ }^{\mathrm{a}}$ Represents number of dogs.

${ }^{\mathrm{b}}$ Weighted by number of dogs.

${ }_{\mathrm{c}}^{\mathrm{c}}$ One dog was used for half the year.

${ }^{\mathrm{d}}$ Estimated by multiplying the average number of ewes and lambs/producer by differences in predation rates for producers with and without dogs, multiplying by the average value of sheep, and dividing by the average number of dogs/producer. 
1993 in Colorado (Colorado Agricultural Statistics Service 1994, 1997). We also found that the number of producers using guard dogs and the number of sheep with dogs increased significantly in Colorado between 1986 and 1993 even though the number of sheep producers declined. Colorado Agricultural Statistics Service (1995b, 1998) reported $30 \%$ of sheep producers in Colorado used guard dogs in 1994 and 44\% used guard animals (perhaps mostly guard dogs) in 1997 suggesting a continued increase in use of dogs. Our data indicate that larger percentages of animals are being protected by dogs rather than proportions of producers who have dogs. Most producers without guard dogs on open range who we surveyed in 1986 obtained dogs by 1993 . These data indicate that primarily the larger producers have incorporated dogs.

Although not statistically significant, predation tended to increase from 1986 to 1993 in herds guarded by dogs. We found that the proportion of ewes and lambs killed by predators increased with the size of operations using guard dogs in 1993. Thus, the increase in predation from 1986 to 1993 in guarded herds may be related to the larger size of operations in 1993 compared to 1986.

Green and Woodruff (1989) and Green et al. (1993) reported that guard dogs repelled black and grizzly bears during most encounters. We found that producers using guard dogs, compared to producers without dogs, sustained lower predation on ewes and lambs by black bears and mountain lions, and rated dogs as successful for deterring those losses. These observations indicate guard dogs can be successful against large carnivores.

Coppinger et al. (1988) and Green and Woodruff (1990) reported that effectiveness of guard dogs did not differ between fenced pasture and open range operations. We also found that producer ratings of guard dogs did not differ between fenced pasture and open range operators for deterring predation by predators, and specifically coyotes and domestic dogs, but guard dogs were rated as more effective in fenced pastures than on open range against black bears and mountain lions. Our data on sheep killed by black bears and mountain lions suggests the opposite with guard dogs being more effective on open range than in fenced pastures. Producers using guard dogs also sustained higher mortalities to predators, especially coyotes, on open range compared to fenced pastures, and reported that each dog saved a larger value of sheep on open range than in fenced pastures which probably was due to having larger herds of sheep on open range.

Coppinger et al. (1983) reported that guard dog performance was similar between small and large flocks of sheep. Green and Woodruff (1983a) reported that 2 or more dogs, compared to 1 dog, provided better protection of sheep from predators, but no data were provided. We found that proportions of ewes reported killed by predators on open range were directly related to the size of the herd with dogs. However, our direct relationship between proportions of sheep killed by predators in all operations combined versus the number of sheep in an operation may not reflect greater mortalities with greater herd size, but may be related to greater mortalities on open range than in fenced pastures and the associated larger herds on open range.

Mortalities to predators in this study did not vary with the number of ewes or lambs/guard dog nor with the number of dogs/herd of sheep. This relationship does not necessarily mean that the number of ewes or lambs/dog or the number of dogs/herd does not affect predation rates. Rather, this relationship may reflect producers adjusting numbers of ewes or lambs/dog or numbers of dogs/herd for each operation until mortalities are reduced to a certain level.

We surveyed more producers with sheep in fenced pastures than on open range, however, our mortality rates for all operations combined generally emphasize rates on open range because we weighted our analyses by herd sizes which were much larger on open range. Mortality rates to coyotes likely are reflective of mortality rates across Colorado because coyotes were reported in the area of practically all fenced pasture and open range operations that we surveyed. However, mortality rates to black bears and mountain lions likely exaggerates mortality rates across Colorado, especially in fenced pastures, because our data represent mortalities where these predators were present, and only about one-third of the producers in fenced pastures indicated black bears and mountain lions were found in their areas.

Colorado Agricultural Statistics Service (1995b) estimated that predators killed $\$ 2.20$ million of sheep and lambs in Colorado during 1994. Estimated total numbers of mature sheep and lamb mortalities divided by the inventory of breeding sheep $(320,000)$ and annual lamb crop (255,000; Colorado Agricultural Statistics Service 1995a) indicate that predators killed $2.0 \%$ of ewes and $11.4 \%$ of lambs which was similar to our percentages for producers without guard dogs. Mortality rates to coyotes, black bears, mountain lions, and domestic dogs also were similar for the 2 surveys. Coyotes were the major predator of lambs in both surveys. In our study, producers estimated that their guard dogs saved $\$ 891,440$ of sheep from predation during 1993. This savings has an economic "multiplier effect" of about 2.7 (Hoag et al. 1995) which suggests the use of guard dogs added about $\$ 2.4$ million of value to Colorado's economy during 1993.

Producer estimates were higher than our estimates of the average value of sheep saved/guard dog in all operations combined and in fenced pastures. Producer estimates were based upon mortalities before compared to after obtaining dogs, whereas our estimates were based upon producers with and without dogs. These differences could be explained if producers that obtained dogs had higher mortalities before obtaining dogs than producers that did not obtain dogs. Our estimates were higher than producer estimates of the average value of sheep saved/dog on open range. These differences could be based upon our limited sample size for estimating predation rates for producers without dogs.

Producer estimates of the average value of sheep saved/dog/year from predators in fenced pastures $(\$ 1,149)$ and on open range $(\$ 3,610)$ in this study exceeds the purchase price of guard dog pups (\$240) and adults (\$690) plus $\$ 26$ in shipping fees (Andelt 1985) and annual maintenance (food, veterinary care, and miscellaneous costs) which averaged \$250 (Andelt 1985) and \$286 (Green et al. 1984)/year. The value of each guard dog increased with the number of sheep that producers maintained in fenced pastures but not on open range. This probably resulted because the number of guard dogs increased with the number of sheep owned by individual producers on open range, but not in fenced pastures.

We found that most producers indicated effectiveness of their dogs did not change with time and, of the producers indicating effectiveness changed, more producers felt their dogs became more effective. In addition, ewe and lamb mortalities to predators decreased with the number of years producers used dogs. Thus, our data concur with a subset of the data (Green et al. 1994) indicating performance of the majority of dogs remained the same or improved with time. 


\section{Conclusions and Management Recommendations}

Guard dogs are an important tool for reducing sheep mortalities to predators. Producers with guard dogs, compared to producers without dogs, lost smaller proportions of their lambs to predators, specifically to coyotes, and also lost smaller proportions of their sheep to black bears and mountain lions. Ewe and lamb predation generally was lower for producers who obtained dogs relative to producers who had not obtained dogs. In addition, $84 \%$ of producers rated the effectiveness of their dogs as excellent or good, most producers indicated that their dogs did not decrease effectiveness with time, $>96 \%$ of producers indicated that they would recommend dogs to other producers, all 17 producers that used dogs in 1986 and continued in the sheep business still used dogs in 1993 and 125 producers using guard dogs in 1993 indicated that their dogs saved over $\$ 891,000$ in sheep from predators; these estimates of savings were conservative because 32 producers did not provide estimates. Thus, use of guard dogs is a successful method for combating predation on domestic sheep.

In a recent synthesis of coyote and depredation control literature, Knowlton et al. (1999) suggest that there may be a difference in predation risk between pastured sheep and those on open range. We found lambs on open range are significantly more likely to be killed by predators than those in fenced pastures. Knowlton et al. (1999) also report that no techniques to control depredations are universally effective and that guard dogs are effective in some situations but not in others. Based on our data and the opinions of nearly all producers, dogs, when properly used, are effective in the majority of situations against a variety of predators. However, it is interesting to note that according to our data, guard dogs do not significantly change predation rates on ewes from coyotes or domestic dogs regardless of the operation, but do significantly protect lambs. Ewes might be more capable of defending themselves against canids, and the effects of guard dogs may be less apparent. On the other hand, lambs are more vulnerable to coyotes, and they often are maintained with ewes which likely reduces predation on ewes, and makes the effects of guard dogs less apparent. Guard dogs do not eliminate all depredation losses but significantly reduce them, and they are economically effective. On the basis of our data and opinions of producers, we recommend guard dogs as essential components of sheep production in Colorado, especially to protect lambs against coyotes, to protect ewes and lambs against black bears, mountain lions, and domestic dogs, and especially for producers using open rangelands.

\section{Literature Cited}

Andelt, W. F. 1985. Livestock guarding dogs protect domestic sheep from coyote predation in Kansas. Proc. Great Plains Wildl. Damage Control Workshop 7:111-113.

Andelt, W. F. 1992. Effectiveness of livestock guarding dogs for reducing predation on domestic sheep. Wildl. Soc. Bull. 20:55-62.

Andelt, W. F. 1996. Carnivores. p. 133-155. In: P. R. Krausman (ed.), Rangeland wildlife. The Soc. Range Manage., Denver, Colo.

Colorado Agricultural Statistics Service. 1993. Colorado agricultural statistics 1993 Colo. Ag. Stat. Serv., Lakewood, Colo.

Colorado Agricultural Statistics Service. 1994. Colorado agricultural statistics 1994. Colo. Ag. Stat. Serv., Lakewood, Colo.

Colorado Agricultural Statistics Service. 1995a. Colorado Agricultural Statistics 1995. Colo. Ag. Stat. Serv., Lakewood, Colo.

Colorado Agricultural Statistics Service. 1995b. Sheep and lamb death loss-1994. Colo. Ag. Stat. Serv., Lakewood, Colo.

Colorado Agricultural Statistics Service. 1997. Colorado agricultural statistics 1997. Colo. Ag. Stat. Serv., Lakewood, Colo.

Colorado Agricultural Statistics Service. 1998. Colorado sheep and lamb losses1997. Colo. Ag. Stat. Serv., Lakewood, Colo.

Coppinger, R., J. Lorenz, and L. Coppinger. 1983. Introducing livestock guarding dogs to sheep and goat producers. Proc. East. Wildl. Damage Contr. Conf. 1:129-132.

Coppinger, R., L. Coppinger, G. Langeloh, L. Gettler, and J. Lorenz. 1988. A decade of use of livestock guarding dogs. Proc. Vertebr. Pest Conf. 13:209-214.

Green, J. S. and R. A. Woodruff. 1983a. The use of Eurasian dogs to protect sheep from predators in North America: a summary of research at the U.S. Sheep Exp. Station. Proc. East. Wildl. Damage Control Conf. 1:119-124

Green, J. S. and R. A. Woodruff. 1983b. The use of three breeds of dog to protect rangeland sheep from predators. Appl. Anim. Ethol. 11:141-161.

Green, J. S. and R. A. Woodruff. 1988. Breed comparisons and characteristics of use of livestock guarding dogs. J. Range Manage. 41:249-251.

Green, J. S. and R. A. Woodruff. 1989. Livestock-guarding dogs reduce depredation by bears. p. 49-54. In: M. Bromley (ed.), Bear-people conflicts: proceedings of a symposium on management strategies. Northwest Terr. Dep. Renew. Res., Yellowknife, Northwest Territories.
Green, J. S. and R. A. Woodruff. 1990. ADC guarding dog program update: a focus on managing dogs. Proc. Vertebr. Pest Conf. 14:233-236

Green, J. S., R. A. Woodruff, and W. F. Andelt. 1994. Do livestock guarding dogs lose their effectiveness over time? Proc. Vertebr. Pest Conf. 16:41-44.

Green, J. S., R. A. Woodruff, and T. T. Tueller. 1984. Livestock-guarding dogs for predator control: costs, benefits, and practicality. Wildl. Soc. Bull. 12:44-50.

Green, J. S., R. A. Woodruff, and P. J. Wick. 1993. Bears, ostriches, and specialized grazing: putting guarding dogs to work. Proc. Great Plains Wildl. Damage Control Workshop 11:105-108.

Hoag, D. L., J. R. Fulton, and E. Hornbrook. 1995. Colorado's farm and food system: its contribution to the state economy in 1992. Colo. State Univ. Coop. Ext. Bull. 551A, Fort Collins, Colo.

Knowlton, F. F, E. M. Gese, and M. M. Jaeger. 1999. Coyote depredation control: An interface between biology and management. J. Range Manage. 52:398-412.

Linhart, S. B., R. T. Sterner, T. C. Carrigan, and D. R. Henne. 1979. Komondor guard dogs reduce sheep losses to coyotes: a preliminary evaluation. J. Range Manage. 32:238-241.

McGrew, J. C. and C. S. Blakesley. 1982. How Komondor dogs reduce sheep losses to coyotes. J. Range Manage. 35:693-696.

Milliken, G.A. and D. E. Johnson. 1984. Analysis of messy data. Volume 1: Designed experiments. Lifetime Learning Pub., Belmont, Calif.

National Agricultural Statistics Service. 1995. Sheep and Iamb death loss 1994. USDA, Nat. Agr. Statistics Service., NASS Staff Rep. LDP No. 95-01, Washington, D.C.

Pearson, E. W. 1986. A literature review of livestock losses to predators in western U.S. U.S. Fish and Wildl. Serv. Final Rep., Denver, Colo.

SAS Institute Inc. 1988. SAS/STAT User's guide, release 6.03 edition, SAS Inst., Cary, N.C. 